\title{
矩形開口を有するコンクリート系梁の終局強度 \\ ULTIMATE STRENGTH OF STRUCTURAL CONCRETE BEAM WITH RECTANGULAR WEB OPENING
}

\author{
浜原正行*, 石井明男****, 未次宏光**, 中山 優*** \\ Masayuki HAMAHARA, Akio ISHII, Hiromitsu SUETSUGU \\ and Yasashi NAKAYAMA
}

The AlJ "Design Guideline for Earthquake Resistant Reinforced Concrete Buildings Based on Inelastic Displacement Concept" requires that the shear carried by arch action shall be ignored in the reinforced concrete beams with openings. The validity of this requirement, however, has not been verified yet. In this paper, 12 reinforced concrete short beams with web openings were loaded monotonically, in order to investigate the arch mechanism in the solid portions. The test variables were the size and location of the openings, bond performance of longitudinal reinforcement (i.e. bond or no bond) and the shear span. The conclusions obtained from this investigation were as follows.

1) The shear carried by arch action existed in the test beams having axial reinforcement with no bond.

2) The ultimate strength of the test beams'was given by the smaller between the ultimate strength in the solid portion and the one in the openings.

Keywords : reinforced and prestressed concrete beams, arch action, bond performance, web openings, ultimate strength 鉄筋コンクリート梁, アーチ作用，付着性能，開口，終局強度

\section{1 はじめに}

近年，わが国では，鉄筋コンクリート(以後、RC) 造終局強度型指針 1)や RC 造䩕性保証型指針 ${ }^{2)} に$ 見られるようなトラス・アーチモデルを 用いたせん断設計法が定着しつつある.これらの指針では，有孔梁の 設計はこのせん断理論の伜組みの中で論じら扎ているが, 無開口梁と 異なり，母材はアーチ作用によるせん断力が考慮されていない。この ことは，母材が本来有している耐力が開口によって低減されることを 意味している.

周知のように,アーチモデルは付着のない軸方向鋼材と材を対角線 方向に結ぶコンクリート圧縮束によって構成される．この圧縮束の中 に開口を設置すると，その応力の流れは開口によって遮断される.こ れに伴い,ア一チ作用によるせん断力の伝達も阻害されることになる 上記の指針でアーチ作用による負担せん断力を無視するとしている のはこのような事情による.

文献 3)では，曲げ卓越型の梁に開口を設けても母材本来の耐力は 低減せず, 有孔梁としての終局強度は母材の曲げ終局強度と開口部の 終局強度のいずれか小さいほうの值で与えられることを示している. 文献 4)では，アーチ作用を実験的に再現するだめに軸筋の付着を除 去したせん断スパン比 1 と1.5のRC梁に対する逆対称載荷実験を実 施した. この実験より，コンクリートの圧縮主ひずみは縁で最大とな
り、縁から離れるにしたがって減少すること,したがって、アーチモ デルに対応するような材の対角線方向主ひずみの增加は見られなか ったことが示されている.この結果は,アーチモテルは部材のせん断 終局強度の推定には有效であるが、実際の梁のひずみ性状を再現でき ない場合があることを意味している.

軸筋が付着䢻失した部材が上述のような曲げ部材に類似したひず み性状を示すなら、このような梁に開口を設けても、文嗝 3)の試験 体同様、母材が本来有している耐力は低減しないと考えられる.

本報告では，まず，せん断スパン比，開口の寸法，位置，形状，お よび主筋の付着の有無を要因とする 12 体の有孔梁試䤣体に対して一 方向渐増載荷実験を行い，これらの要因が有孔梁の終局強度に及ぼす 影響を実験的に検討する. 次に, 上記の試験体に 8 体の PCaPC 有孔 梁試験体 5)を含めた 20 体の試験体の終局強度が，母材の終局強度と 開口部の終局強度上のうち，いずれか小さい方の值で評価できるか杏 かについて考察檢討を加えようとするものである.なお、材の終局 強度とは、無開口梁としての終局強度のことである。

\section{2 范号}

$a_{o}:$ 反曲点から開口中心までの距離 $(\mathrm{mm})$

$b, D, d, L:$ 母材の幅，同全せい，同有勃せい，同内法スパン $(\mathrm{mm})$

\footnotetext{
* 日本大学理工学部海洋建築工学科 助教授. 工博

* 日本大学理工学部海洋建築工学科 教授. 工博

*** 日本大学短期大学部建設学科 教授・工博

**** 東武谷内田建設侏
}

\author{
Assoc. Prof., Dept. of Oceanic Architecture \& Engineering, College of Science and \\ Technology, Nihon Univ., Dr. Eng. \\ Prof., Dept. of Oceanic Architecture \& Engineering, College of Science and \\ Technology, Nihon Univ., Dr. Eng. \\ Prof., Dept. of Construction, Junior College, Nihon Univ., Dr. Eng \\ Tohbu-Yachida Construction Co.
}


$d_{o}$ : 開口部の上弦材の重心から下弦材の重心までの問距離 $(\mathrm{mm})$ $h_{o} ， L_{\infty}$ : 開口部の上弦材または下弦材のせい，開口の長さ $(\mathrm{mm})$ $j_{o}$ : 開口部の上弦材または下弦材におけるトラスモデルのせい $(\mathrm{mm})$ $N_{L} ， N_{2}$ : 上弦材に作用する偶力，下弦材に作用する偶力 $(\mathrm{kN})$

$f_{w y}, p_{w}$ : 肋筋の降伏点 $\left(\mathrm{N} / \mathrm{mm}^{2}\right)$, 动筋比

$Q_{a 1} ， Q_{a 2}$ : 上弦材，下弦材のア一千作用によるせん断力 $(\mathrm{kN})$

$Q_{w 1} ， Q_{W 2}$ : 上弦材，下弦材のトラス作用によるせ九断力 $(\mathrm{kN})$

$Q_{M}, Q_{S}:$ 母材の曲け終局強度，同せん断終局強度 $(\mathrm{kN})$

$Q_{u o}:$ 開口部の終局強度 $(\mathrm{kN})$

$T_{y}$ : 母材の上端筋または下端筋の降伏荷重 $(\mathrm{kN})$

$T_{e y}, T_{e y}{ }^{\prime}$ : 開口部の上弦材または下弦材を通る軸方向龬材の中で母材 の縁側に配置されたものの降伏荷重(付着有)，同(付着無) $(\mathrm{kN})$ $T_{i y}$ : 開口部の上弦材または下弦材を通る軸方向鋼材の中で開口側に

配置されたものの降伏荷重(本試験体はいずれも付着有) $(\mathrm{kN})$

$\nu$ : コンクリート圧樎強度の有効倸数

\section{3 実呀概要}

実験要因はせん断スパン比 $a / D$, 開口の寸法, 位置, 形状, および 軸筋の付着の有無である. 表 1 に試験体の諸元を, 図 1 に配筋詳細の 一例示す。なお，付着のない上端筋と下端筋には，シリーズIではア ンボンド PC 鋼棒を, その他のシリーズでは試験区間をワックスで梁 布した上にビニールテーブを巻いた異型鉄筋を用いた。

載荷形式は図 2 に示すように $500 \mathrm{kN}$ ジャッキを用いた逆対称一方 向渐增載荷とした。自由端側の $100 \mathrm{kN}$ ジャッキは加力用鉄骨とス夕 ブの重量を支えた.このジャッキはスタブと加力用鉄骨の重心位置

\section{表 1 試挽体概要}

\begin{tabular}{|c|c|c|c|c|c|c|c|c|c|}
\hline \multirow{2}{*}{$\begin{array}{l}\dot{*} \\
\text { U } \\
\text { I } \\
\text { X }\end{array}$} & \multirow{2}{*}{$\begin{array}{l}\text { 試 } \\
\text { 鋁 } \\
\text { 体 } \\
\text { 名 }\end{array}$} & \multirow{2}{*}{$\begin{array}{l}\text { 軸 } \\
\text { 管 } \\
\text { 付 } \\
\text { 著 }\end{array}$} & \multirow{2}{*}{$a / D$} & \multicolumn{3}{|c|}{ 開口の寸法 (mm) } & \multirow{2}{*}{$\begin{array}{l}\text { 開 } \\
\text { 口 } \\
\text { 位 } \\
\text { 鮎 }\end{array}$} & \multicolumn{2}{|c|}{$\begin{array}{l}\text { 開口部弦材の } \\
\text { 軸方向補强肪 } \\
\end{array}$} \\
\hline & & & & $L_{0}$ & $H_{0}$ & $H_{o}$ & & 梁緑側 & 開口僓 \\
\hline \multirow{3}{*}{1} & A1 & \multirow{3}{*}{ 無 } & 1 & \multirow[t]{2}{*}{90} & \multirow[t]{2}{*}{90} & \multirow[t]{2}{*}{180} & \multirow{3}{*}{$\begin{array}{l}\text { 中 } \\
\text { 央 }\end{array}$} & ---- & $-\infty-$ \\
\hline & A2 & & 1.5 & & & & & & \\
\hline & $\frac{\mathrm{A} 3}{\mathrm{~A} 4}$ & & $\frac{1}{1.5}$ & 300 & 150 & 150 & & 1-D19 & $2-013$ \\
\hline \multirow{2}{*}{ II } & $\overline{B 1}$ & 市 & \multirow{2}{*}{1} & \multirow{2}{*}{300} & \multirow{2}{*}{150} & \multirow{2}{*}{150} & 中 & \multirow{2}{*}{----} & \multirow{2}{*}{$2-013$} \\
\hline & $\mathrm{B} 2$ & 無 & & & & & 央 & & \\
\hline \multirow{4}{*}{ III } & $\mathrm{Cl}$ & 有 & \multirow{4}{*}{1} & \multirow{4}{*}{200} & \multirow{4}{*}{200} & \multirow{4}{*}{125} & 端 & \multirow{4}{*}{---- } & \multirow{4}{*}{ 2-D13 } \\
\hline & $\mathrm{C} 2$ & 無 & & & & & 部 & & \\
\hline & $\mathrm{C3}$ & 有 & & & & & 中 & & \\
\hline & $\mathrm{C} 4$ & 無 & & & & & 央 & & \\
\hline \multirow{2}{*}{ IV } & D1 & $\begin{array}{l}\text { 無 } \\
\end{array}$ & \multirow{2}{*}{1} & \multirow{2}{*}{200} & \multirow{2}{*}{200} & \multirow{2}{*}{125} & 中 & --- & 2-D13 \\
\hline & $D 2^{2}$ & 無 & & & & & 央 & & \\
\hline
\end{tabular}

*開口形状は円形で $L o, H o$ は開口の直径

[共通因子] $b=200 \mathrm{~mm}, D=450 \mathrm{~mm}, t=410 \mathrm{~m}$

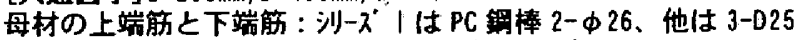
助能 $=$ 目材、開口部の弦材共 $\left[D 6\right.$-@ $75\left(p_{w}=0.4 \%\right)$

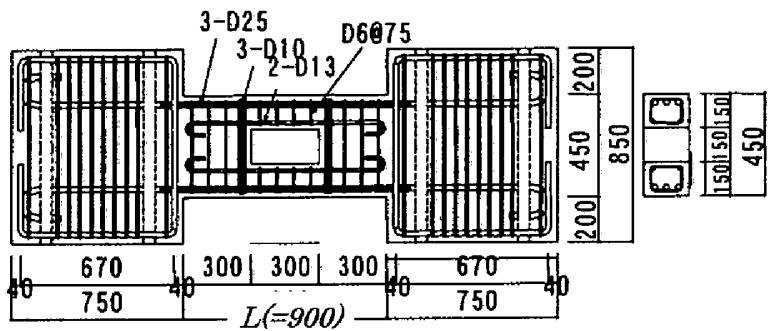

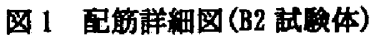

から(1)式による偏心距離分 先端に寄った位置に設置した。

$$
e=\omega \cdot L^{2} /\left\{4 \cdot\left(W_{s}+W_{c}\right)\right\}
$$

ここに， $\omega=$ 試験体梁部分の単位長さ当たりの重量 $(\mathrm{N} / \mathrm{mm})$

$W_{s}, W_{c}=$ 加力鉄骨治具とスタブの重量 $(\mathrm{N})$

これより,梁の右端の曲げモーメント $\left(M_{R}\right)$ と左端の曲げモーメント $\left(M_{I}\right)$ は，それぞれ(1b)，(1c)式で与えられ、両端の曲げモーメントは 逆対称となる。

$$
\begin{aligned}
& M_{R}=\left(W_{s}+W_{c}\right) \cdot e=\omega \cdot L^{2} / 4 \\
& M_{L}=\left(W_{S}+W_{c}\right) \cdot e-\omega \cdot L^{2} / 2=-\omega \cdot L^{2} / 4
\end{aligned}
$$

載荷中は, 左右スタブの回転角が等しくなるよう, このジャッキで 制御した. 相対変形角 $\mathrm{R}$ の測定は图 2 に示す $D 1, D 2$ の二台の電気式 変位計を用い，(2)式で求めた。

$$
R=\left\{(1 / 2) \cdot\left(D_{1}+D_{2}\right)\right\} / L
$$

\begin{tabular}{|c|c|c|c|c|c|c|c|c|}
\hline \multirow{2}{*}{$\begin{array}{l}\dot{y} \\
\text { リ } \\
\text { I } \\
\text { ス }\end{array}$} & \multirow[b]{2}{*}{$\begin{array}{r}x ラ シ フ^{\circ} \\
(\mathrm{mm})\end{array}$} & \multirow[b]{2}{*}{$\begin{array}{c}A \\
(\mathbf{X})\end{array}$} & \multirow[b]{2}{*}{$\begin{array}{l}w / C \\
(y)\end{array}$} & \multirow[b]{2}{*}{$\begin{array}{c}D_{m a x} \\
(\mathrm{~mm})\end{array}$} & \multicolumn{4}{|c|}{ 単位重量 $\left(\mathrm{kg} / \mathrm{m}^{\mathrm{J}}\right)$} \\
\hline & & & & & 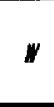 & $c$ & $s$ & $G$ \\
\hline 1 & \multirow{3}{*}{80} & \multirow{3}{*}{2.0} & 65 & 20 & 165 & 254 & 920 & 1005 \\
\hline II & & & 67 & 25 & 175 & 261 & 904 & 987 \\
\hline III & & & 65 & 20 & 165 & 254 & 898 & 984 \\
\hline IV & 210 & 4.5 & 56 & 20 & 196 & 354 & 784 & 923 \\
\hline
\end{tabular}

表 2 にコンクリートの調合表, 表 3，4 にコンクリートと鎍材の材 料試験結果を示す。

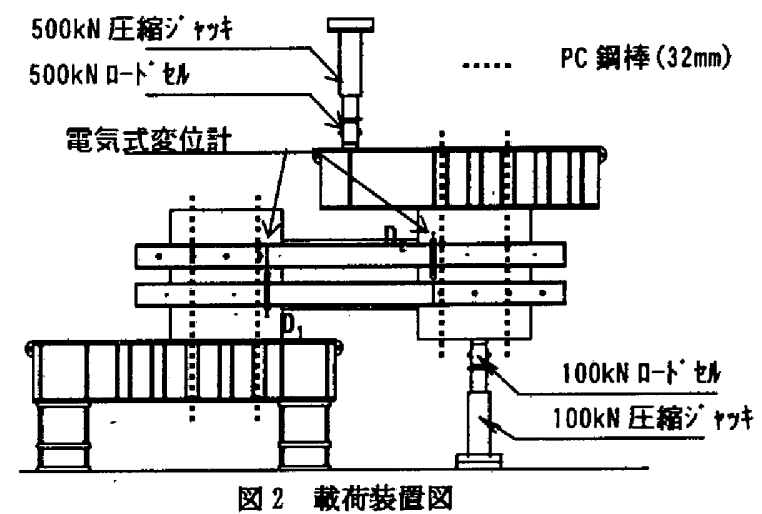

\begin{tabular}{|c|c|c|c|c|c|c|}
\hline 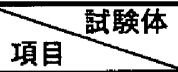 & A) & A2 & A3 & A4 & B1 & B2 \\
\hline$\sigma_{B}\left(\mathrm{~N} / \mathrm{mm}^{2}\right)$ & 39.5 & 39.5 & 41.3 & 41.3 & 34.1 & 30.6 \\
\hline$E\left(\mathrm{kN} / \mathrm{mm}^{2}\right)$ & 33.1 & 33.1 & 32.8 & 32.8 & 28.3 & 28.6 \\
\hline$\sigma_{\mathrm{T}}\left(\mathrm{N} / \mathrm{mm}^{2}\right)$ & 3.36 & 3.36 & 3.53 & 3.53 & 3.11 & 3.75 \\
\hline 項目 ${ }^{\text {㢦験体 }}$ & $\mathrm{Cl}$ & $\mathrm{C} 2$ & C3 & C4 & D1 & D2 \\
\hline$\sigma_{B}\left(\mathrm{~N} / \mathrm{mm}^{2}\right)$ & 38.5 & 37.5 & 35.9 & 32.8 & 22.7 & 22.7 \\
\hline$E\left(\mathrm{kN} / \mathrm{mm}^{2}\right)$ & 30.1 & 30.4 & 29.6 & 29.9 & 15.2 & 15.2 \\
\hline$\sigma_{r}\left(\mathrm{~N} / \mathrm{mm}^{2}\right)$ & 2.88 & 2.77 & 2.87 & 2.51 & 1.64 & 1.64 \\
\hline
\end{tabular}

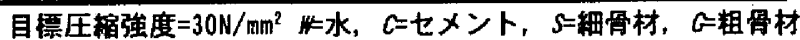
$A=$ 空気冝, $W / C=$ 水セメント比, $D_{\max }=$ 粗骨材の最大寸法,

表 3 コンクリートの材料試緭結果 


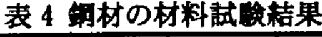

\begin{tabular}{|c|c|c|c|c|c|c|c|}
\hline $\begin{array}{l} \\
\text { y } \\
1 \\
x\end{array}$ & 径 & 使用部位 & 材暒 & $f_{s}$ & $f_{\max }$ & $E_{s}$ & $\begin{array}{l}\text { 伸 } \\
\mho x \\
\text { 率 } \\
\text { (x) } \\
\end{array}$ \\
\hline \multirow{5}{*}{1} & D6 & 母材、弦材の肋筋 & \multirow{3}{*}{ S0295 } & 405 & 588 & 184 & 18.1 \\
\hline & D10 & 开口両側の肋筋 & & 401 & 530 & 196 & 19.2 \\
\hline & 013 & 開口側の開口部補蚛筋 & & 350 & 493 & 188 & 19.2 \\
\hline & D19 & 母材緑側の開口部辅強箭 & SD345 & 375 & 553 & 185 & 19.1 \\
\hline & $\phi 26$ & アンボンドPC 铜捧 & B 掅 & 1177 & 1288 & 200 & 9.0 \\
\hline \multirow{4}{*}{$\|$} & 06 & 母材、弦材の肋筋 & \multirow{3}{*}{ SD295 } & 319 & 478 & 180 & 15.1 \\
\hline & D10 & 開口両例の肋解 & & 386 & 545 & 189 & 17.2 \\
\hline & 013 & 周口側の開口部補強筋 & & 372 & 537 & 189 & 18.9 \\
\hline & $D 25$ & 主筋 & SD345 & 379 & 596 & 185 & 15.3 \\
\hline \multirow{4}{*}{ III } & 06 & 母材、弦材の肋筋 & \multirow{3}{*}{ SD295 } & 327 & 480 & 181 & 16.8 \\
\hline & 010 & 開口両側の肋箭 & & 372 & 505 & 189 & 17.1 \\
\hline & 013 & 開口側の轴方向銅材 & & 344 & 490 & 192 & 18.3 \\
\hline & 025 & 主筋 & SD345 & 360 & 543 & 193 & 19.1 \\
\hline \multirow{4}{*}{ IV } & D6 & 母材、弦材の胑胼 & \multirow{3}{*}{ SD295 } & 383 & 539 & 173 & 17.5 \\
\hline & D10 & 開口両側の肋筋 & & 356 & 499 & 202 & 17,6 \\
\hline & 013 & 開口側の軸方向銚材 & & 347 & 497 & 186 & 18.7 \\
\hline & 025 & 主筋 & SD345 & 386 & 583 & 177 & 24.8 \\
\hline
\end{tabular}

$f_{y}=$ 降伏点 $\left(\mathrm{N} / \mathrm{mm}^{2}\right), f_{m x}=$ 引張強度 $\left(\mathrm{N} / \mathrm{mm}^{2}\right), E_{s}=\uparrow \ni \eta^{\prime}$ 係数 $\left(\mathrm{kN} / \mathrm{mm}^{2}\right)$

\section{4 破塿モードと最大荷重}

因 3，図4は母材主䈘の付着を除去したシリーズIにおける試験体 の最終破㙥状況と荷重一部材角関係をせん断スパン比別に示したも のである. せん断スパン比 1 の試験体は, 開口寸法 $90 \mathrm{~mm}$ 角の A1 が母材端部のコンクリートの圧壊, 開口寸法 $150 \mathrm{~mm} \times 300 \mathrm{~mm} の \mathrm{~A} 3$ が開口部弦材のせん断破罴によって軕力低下を起こした.この 2 体の 耐力と勒性を比較すると， $\mathrm{A} 1$ は最大荷重 $300 \mathrm{kN}$ を超え，比較的勒性 にも富んでいたのに対し，A3 は最大荷重が A1 の2/3にも達してお らず，判性にも乏しい，せん断スパン比 1.5 の試験体(A2，A4)は，開 口寸法に関保なく母材端部のコンクリートの圧壊によって耐力低下 を起こした.これらの試験体は開口寸法に関係なくいずれも最大荷重 が約 $200 \mathrm{kN}$ であり，勒性にも比較的富んでいる．軸筋の付着を除去 し，母材のトラス作用が期待できないような有孔梁でも，十分な耐力 を保持し得る場合がある.
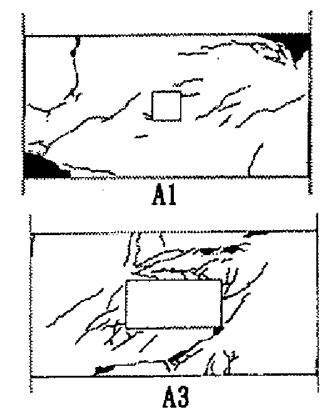

图 3 最格破塿状涀(シリーズ I )
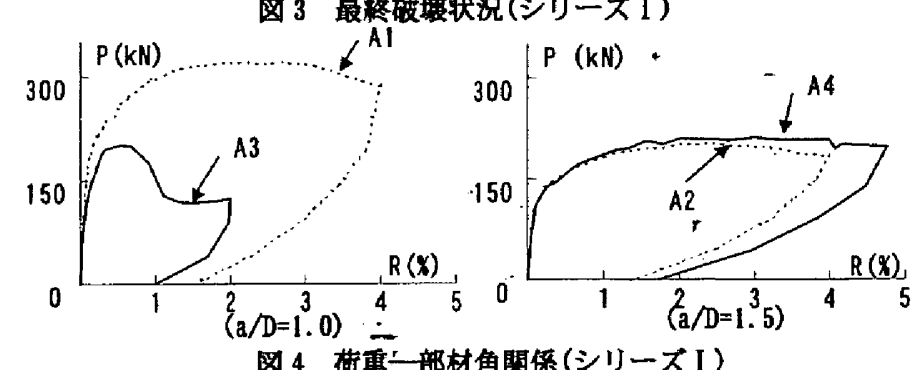

图 4 荷重一部村角閶俰 (シリーズ I)
図 5(a)，(b)は母材主筋の付着の有無が試駼体の最終破壊状況之荷重 一部材角関倸に及ほすす影響を調べたものである. 主䇢の付着を除去し なかった試験体 B1，主筋の付着を除去した試験体 B2 とも開口部弦 材のせん断破萝によって耐力低下した．主箭の付着を除去した B2 は B1 と比較するとひび割れ本数が少ない，また，B2 の最大荷重は B1 の約 2/3である.トラス作用の成立条件は、そのメカニズム上、軸筋 に付着が確保されていることである。したがって、軸筋の付着を除去 した B2 は開口部妵材でのトラス作用を発揮できないことになる。上 記の結果はこのことに起因している.また、このような傾向はショー ズIIIの試験体にも見られた。

シリーズNの試駼体はいずれも開口部弦材でせん断破壊したが、開 口寸法が矩形の試験体(D1)の最大荷重は円形の試験体(D2)の約 $60 \%$ であった。
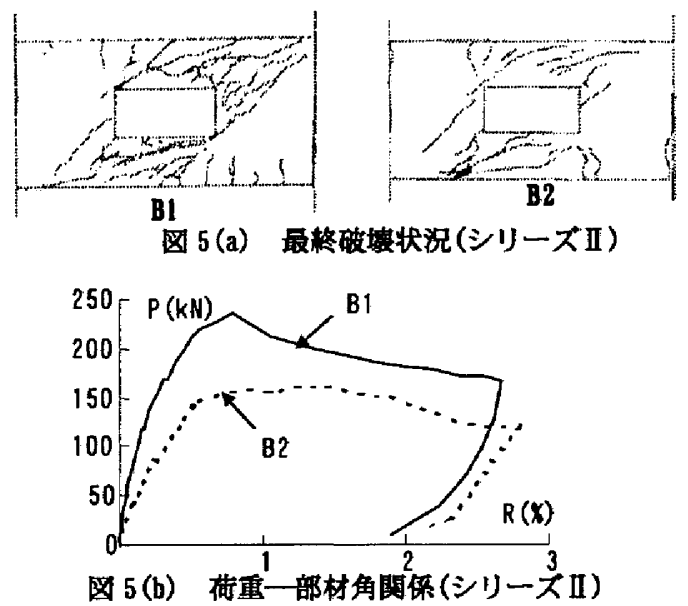

\section{5 䅂局強度に対する検封}

本節では，母材のトラス作用が発揮されないように主筋の付着を除 去した有孔梁試駼体やトラスとアーチが混在していると考えられる 通常の有孔梁試験体の終局強度が, 曲け卓越型の梁に開口を設けた場 合同様，母材と開口部の終局強度のうち，いずれか小さい方の值で評 価できるか否かについて検討を加える。

\section{1 解析に用いた試䎥体}

表 5 に解析に用いた諸元の一筧を示す。検討には，4節までで触れ たシリーズ I 〜Nの 12 体の試験体に文献 5)に掦載されている8体の $\mathrm{PCaPC}$ 有孔梁試験体(表 5 中, $\mathrm{P} 1 \sim \mathrm{P} 8$ )を含めた 20 体分の害験資料 を用いた. P1〜P8には，図 2 と同じ逆対称载荷を採用し，加力ルー ルは正負繰り返し載荷とした. 表 5 中に記載したこれらの試雅体の最 大荷重 $Q_{e u}$ は正負の平均値である. 图 6 に $\mathrm{PCaPC}$ 試駼体の配筋詳細 の一例を示す。

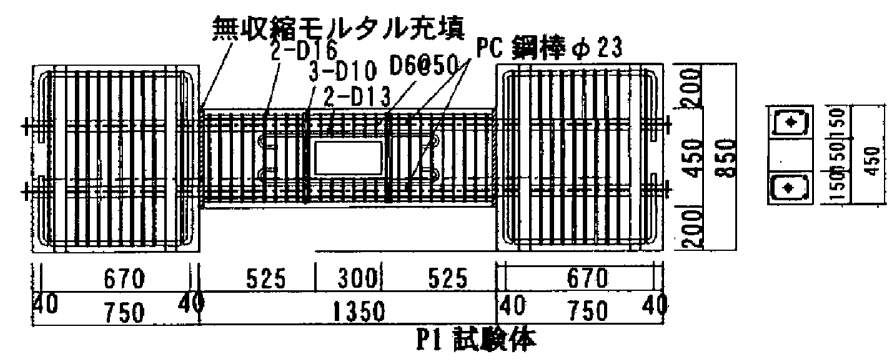

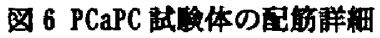




\section{2 解析に除しての仮定}

本解析は矩形開口を有するコンクリート系部材を対象としている。 開口形状が円形の試験体については、開口面積が等しい矩形開口に置 き換えて計算した。試験体の終局強度の算定に際しては, 以下に示す 仮定を設定した。

(1) 試験体の終局強度は，それぞれ独立に算定した母材と開口部の 終局強度のうち小さい方の値として与えられる。

(2) 母材の終局強度は曲げとせん断のうち小さい方の值で与えられ る。せん断終局強度は压縮斜材角度 45 度のトラス作用とア一于作用 によるせん断力の和で与えられる. 開口部弦材はフィーレンデール材 として举動し, その終局強度は上弦材強度と下弦材強度の和で表すこ とができる．上弦材と下弦材の終局強度は，それぞれ圧縮斜材角度 45 度のトラス作用とアーチ作用によるせん断力の和で表される.

(3) 開口中心位置での上弦材の曲げモーメントと下弦材の曲けモモー メントの和はゼロである.

(4) $\mathrm{PC}$ 鋼材の応力は庄維に転じることはない。

\section{3 母材の䊏局強度}

\section{曲以攵局強度}

曲け終局強度は下界定理を用いた（3）式で算定したう（図 7)。

$Q_{M}=\left[(1-\lambda) \cdot d+\lambda \cdot D-\frac{(1+\lambda)^{2} \cdot T_{y}}{2 \cdot b \cdot \sigma_{B}}\right] \cdot\left(\frac{T_{y}}{a}\right)$

$d Q_{M} / d \lambda=0$ 上り,$\lambda=\left\{\sigma_{B} \cdot b \cdot(D-d) / T_{y}\right\}-1$

ただし， $1 \geq \lambda \geq-1$ (母材が RC 造） $1 \geq \lambda \geq 0$ (母材が PC 造)

\section{せん断局强鹿}

せん断終局強度は(4)式によって算定した。ただし，主筋の付着を 除去した試験体と丸龬夕イプの PC鉿材を用いた P1〜P8の終局強度 の算定には(5)式に示す主筋降伏を考慮したアーチ耐力式 5)を用いた。

$$
\begin{aligned}
& Q_{S}=p_{w} \cdot f_{w y} \cdot b \cdot j+C_{m}\left[1-\frac{2 \cdot p_{w} \cdot f_{w y}}{v \cdot \sigma_{B}}\right] \cdot \tan \theta \\
& \text { ここに, } \tan \theta=\sqrt{\left(\frac{L}{D}\right)^{2}+1}-\left(\frac{L}{D}\right) \\
& C_{m}=\left(v \cdot \sigma_{B} \cdot b \cdot D\right) / 2 \\
& \left.Q_{s}=C_{m} \cdot \sqrt{2 \cdot\left(\frac{C}{C_{m}}\right)-\left(\frac{C}{C_{m}}\right)^{2}+\left(\frac{L}{D}\right)^{2}}-\left(\frac{L}{D}\right)\right] \\
& C=2 \cdot T_{y} \text { ただし， } C \geqq C_{m} \text { の場合は } C=C_{m} \text { に置き換える. }
\end{aligned}
$$

\begin{tabular}{|c|c|c|c|c|c|c|c|c|c|c|c|c|c|c|c|c|c|c|c|c|c|}
\hline \multirow{3}{*}{$\begin{array}{l}\text { 鴿 } \\
\text { 怢 } \\
\text { 体 } \\
\text { 名 }\end{array}$} & \multirow{3}{*}{$a / D$} & \multicolumn{4}{|c|}{ 母材上端肪，下端胆 } & \multicolumn{4}{|c|}{ 開口位置, 寸法 } & \multicolumn{2}{|c|}{ 弦材肋筋 } & \multicolumn{6}{|c|}{ 詡口部弦材の軸方向鋼材 } & \multirow{3}{*}{$\sigma_{B}$} & \multirow{3}{*}{$P_{e}$} & \multirow{3}{*}{$Q_{e u}$} & \multirow{3}{*}{ 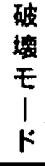 } \\
\hline & & \multirow{2}{*}{$\begin{array}{c}\text { 本数 } \\
\text { 径 }\end{array}$} & \multirow[b]{2}{*}{$T_{y}$} & \multirow[b]{2}{*}{$d$} & \multirow{2}{*}{$\begin{array}{l}\text { 付 } \\
\text { 橥 }\end{array}$} & \multirow[b]{2}{*}{$a_{o}$} & \multirow{2}{*}{$h_{o}$} & \multirow[b]{2}{*}{ jo } & \multirow{2}{*}{$L_{o}$} & \multirow[b]{2}{*}{$p_{w}$} & \multirow[b]{2}{*}{$f_{w y}$} & \multicolumn{2}{|c|}{$\begin{array}{c}\text { 用口側 } \\
\text { (付曾有) }\end{array}$} & \multicolumn{2}{|c|}{$\begin{array}{l}\text { 母材緑俳 } \\
\text { (付猪有) }\end{array}$} & \multicolumn{2}{|c|}{$\begin{array}{l}\text { 母材粶㑡 } \\
\text { (付藉無) }\end{array}$} & & & & \\
\hline & & & & & & & & & & & & $\begin{array}{c}\text { 本数 } \\
\text { 径 }\end{array}$ & $\begin{array}{l}T_{i} \\
y\end{array}$ & $\begin{array}{l}\text { 本数 } \\
\text { 一径 }\end{array}$ & $T_{e y}$ & $\begin{array}{l}\text { 本数 } \\
\text { 一径 } \\
\end{array}$ & $T_{e y}$ & & & & \\
\hline A1 & 1.0 & \multirow{4}{*}{$\begin{array}{c}2 \\
\phi 26\end{array}$} & \multirow{4}{*}{1250} & \multirow{4}{*}{410} & \multirow{4}{*}{ 無 } & & 180 & 110 & 90 & 0 & $\ldots$ & $\cdots$ & 0 & $\cdots$ & 0 & & & 39.5 & 127 & 320.8 & C \\
\hline$A 2$ & 1.5 & & & & & 0 & & 110 & 50 & & 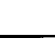 & & & & & $2 \cdot \phi$ & 1250 & 0.0 & 108 & 204.3 & \\
\hline A3 & 1.0 & & & & & 0 & 150 & 80 & 300 & 4 & 405 & 2 & 89 & 1.019 & 108 & 26 & $1<30$ & 413 & 113 & 202.3 & $s$ \\
\hline A4 & 1.5 & & & & & & & & & & & D13 & & & 100 & & & 41.3 & 124 & 212.2 & $\mathrm{C}$ \\
\hline B1 & 10 & 3 & 576 & $\Delta 10$ & 有 & 0 & 150 & 80 & 300 & 4 & 319 & 2 & 95 & 3.025 & 576 & $\cdots$ & 0 & 34.1 & 0 & 235.2 & $s$ \\
\hline B2 & 1.0 & 025 & 510 & 410 & 無 & 0 & 150 & 80 & 500 & & & D13 & & $\cdots$ & 0 & 3-025 & 576 & 30.6 & & 162.1 & \\
\hline $\mathrm{C} 1$ & & & & & 有 & 350 & & & & & & & & 3-D25 & 548 & $\cdots$ & 0 & 38.5 & & 193.9 & \\
\hline C2 & 10 & 3 & 548 & 410 & \begin{tabular}{|l|l} 
無 \\
\end{tabular} & & 125 & 55 & 200 & 4 & 327 & 2 & 87 & $\cdots$ & 0 & 3-025 & 548 & 37.5 & 0 & 115.4 & $s$ \\
\hline $\mathrm{C3}$ & 1.0 & D25 & 340 & 410 & 有 & 0 & 123 & 32 & 600 & .4 & JC1 & D13 & & 3-025 & 548 & $\cdots$ & 0 & 35.9 & 0 & 162.6 & \\
\hline $\mathrm{C} 4$ & & & & & 無 & 0 & & & & & & & & $\cdots$ & 0 & 3-025 & 548 & 32.8 & & 120.4 & \\
\hline D1 & 10 & 3 & 587 & 410 & 無 & 0 & 125 & 55 & 200 & 4 & 383 & 2 & 88 & $\cdots$ & 0 & 3-D25 & 587 & 22.7 & 0 & 72.8 & $S$ \\
\hline D2 & & D25 & & & & & & & & & & D13 & & & & & & & & 122.4 & \\
\hline P1 & 1.5 & 1 & $d 25$ & 375 & & & & & & & & & & & & & & 45.1 & 447 & 227.5 & $C$ \\
\hline$P 2$ & 3.0 & $\phi 26$ & $4<3$ & 310 & & 0 & 150 & 80 & 300 & 6 & 337 & 2 & 99 & 2.D16 & 136 & $\ldots$ & 0 & & 401 & 115.2 & C \\
\hline $\mathrm{P3}$ & 1.5 & 1 & 801 & 375 & & 0 & 100 & 80 & 300 & .0 & Jor & D13 & 35 & CDIv & 100 & & 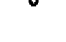 & 527 & 879 & 287.0 & $s$ \\
\hline P4 & 3.0 & $\phi 32$ & & & 無 & & & & & & & & & & & & & & 890 & 159.4 & C \\
\hline $\mathrm{P} 5$ & 1.5 & & & & & 355 & & & & 6 & 337 & & & & & & & 49.9 & 811 & 252.3 & $s$ \\
\hline $\mathrm{P6}$ & 3.0 & 1 & 001 & 375 & & 810 & 150 & 80 & 300 & .0 & (0) & 2 & 99 & 2.0116 & 136 & $\cdots$ & 0 & & 884 & 173.8 & C \\
\hline $\mathrm{P7}$ & 1.5 & $\phi 32$ & ovit & 310 & & 0 & 100 & 00 & 500 & 0 & $\ldots$ & D13 & 50 & 2010 & 100 & & 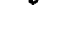 & 58.0 & 861 & 225.6 & $s$ \\
\hline P8 & 3.0 & & & & & & & & & & & & & & & & & & 843 & 167.7 & C \\
\hline
\end{tabular}

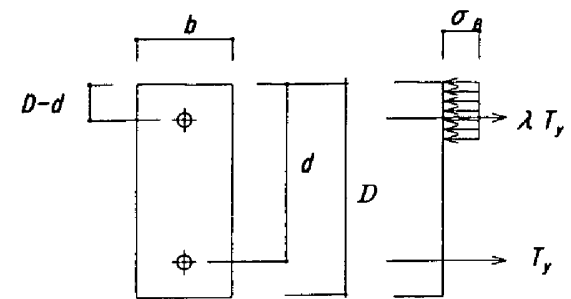

因 7 曲け格局強度の算定

表 5 解析に用いた諸元

[共通因子] 梁幅 $=200 \mathrm{~mm}$ ，梁せい $=450 \mathrm{~mm} \quad \mathrm{~A} 1 \sim \mathrm{D} 2$ の母材胁胼比 $=0.4 \%, \mathrm{P} 1 \sim \mathrm{P} 8$ の母材肋脅比 $=0.6 \%$ 弦材胁筋の降伏点=母材胁筋の降伏点

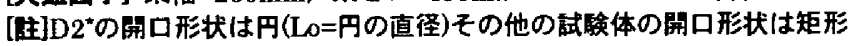

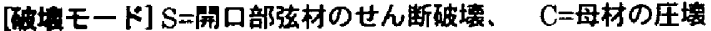

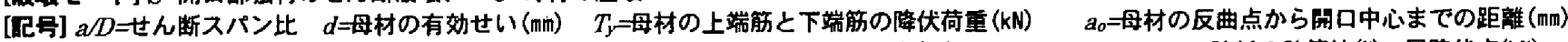

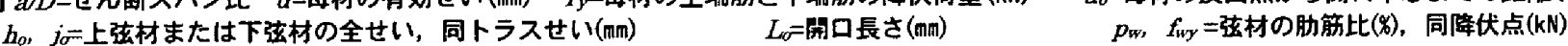

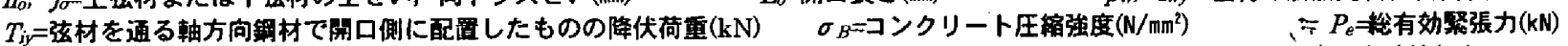

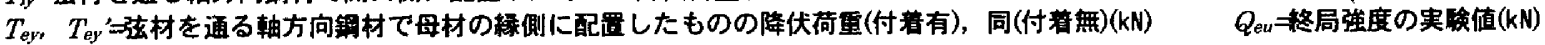




\section{4 開口部の終局強度 ${ }^{2)}$}

\section{符号之記号}

鋼材の応力は引㖘をプラス，圧縮をマイナスとし，コンクリートの 忘力上軸方向力は圧縮をプラス，引張をマイナスとした. 添え字の“1” は上弦材，“2”注下弦材に関連する記号を表している。また，添え 字の “c”㤢樎 “t”は引張に関連する記号を表している.

\section{野析来件}

解析に用いた試験体は，いずれも開口部の上弦材と下弦材の断面 寸法と配筋が同一に設定されている。したがって，解析に際しては 以下に示す諸元が上弦材上下弦材で等しい.

(1) 開口部弦材の全せい $h_{o}$ ，同トラスモデルのせいjo

(2) 助筋比 $\left(p_{w}\right)$ と助筇 $の$ 降伏荷重 $\left(f_{w y}\right)$

(3) 母材の緑側に配置された付着を有する軸方向鎘材の降伏荷重

$\left(\mathrm{T}_{\text {ey }}\right)$ ，同付着を除去した軸方向鎆材の降伏荷重 $\left(T_{e y}\right)$

(4) 開口部側に配置された軸方向鋼材の降伏荷重 $\left(T_{i j}\right)$

\section{トラス作用によるせん断力（図 8)}

上弦材と下弦材のトラス作用によるせん断力 $Q_{\mathrm{w} 1}, Q_{\mathrm{w} 2}$ は(6) 式と (7a) 式〜 (7c) 式で与えられる.

$$
\begin{aligned}
& Q_{w 1}, Q_{w 2}=\min \left({ }_{1} Q_{w, 2} Q_{w, 3} Q_{w}\right) \\
& { }_{1} Q_{w}=p_{w} \cdot f_{w y} \cdot b \cdot j_{o} \\
& { }_{2} Q_{w}=\frac{2 \cdot T_{o y} \cdot j_{o}}{L_{o}+j_{o}} \\
& { }_{3} Q_{w}=\frac{\left(T_{e y}+T_{i y}+T_{e y}{ }^{1}+N\right) \cdot j_{o}}{L_{o}+j_{o}}
\end{aligned}
$$

ここに，(7b)式中の $T_{o y}$ は $T_{e y}$ と $T_{i j}$ のうち, 小さいちの值である.

(7a) 式は開口部弦材の肋筋が降伏したときのせん断力，(7b) 式は開 口部の軸方向龬材が降伏したときのせん断力である. (7c) 式は母材曲 げモーメントによる軸方向力 $\mathrm{N}$ の残余分で構成されるトラスモデル のせん断力であり, 軸方向力の符号が負となる引張を受ける側の弦材 のみに適用される。

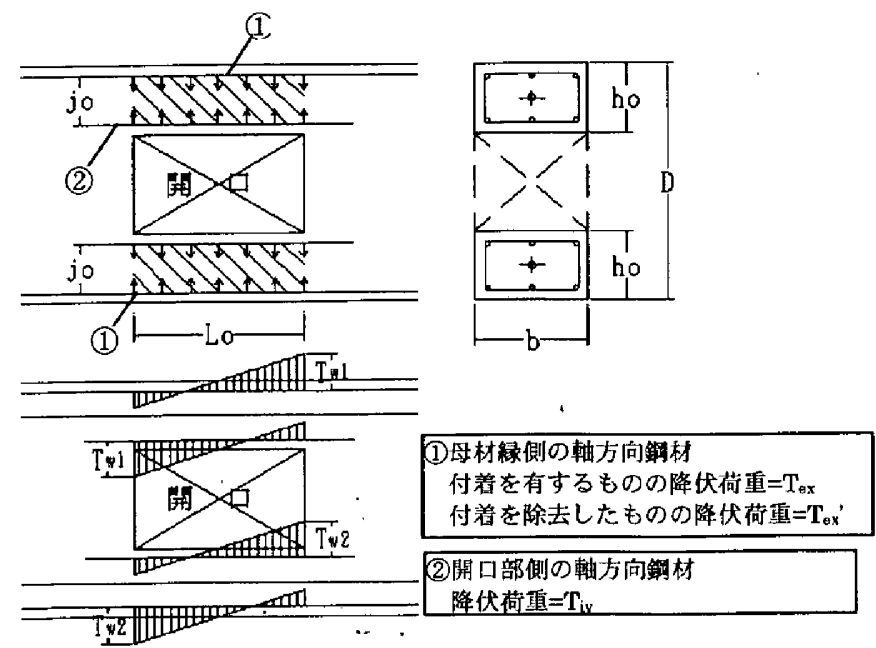

図 8 トラスモデル 上弦材と下弦材の上端筋と下端筋には，(8a) 式に示す引張力 $T_{w l}$, $T_{\mathrm{w} 2}$ と (8b) 式に示す圧維力 $C_{\mathrm{w} 1}, C_{w 2}$ が生じる.

$$
\begin{aligned}
& T_{w 1}=\frac{Q_{w 1}}{2} \cdot\left(\frac{L_{o}}{j_{o}}+1\right) \\
& T_{w 2}=\frac{Q_{w 2}}{2} \cdot\left(\frac{L_{o}}{j_{o}}+1\right) \\
& C_{w 1}=\frac{Q_{w 1}}{2} \cdot\left(\frac{L_{o}}{j_{o}}-1\right) \\
& C_{w 2}=\frac{Q_{w 2}}{2} \cdot\left(\frac{L_{o}}{j_{o}}-1\right)
\end{aligned}
$$

上弦材と下弦材のコンクリート斜材には(9)式に示す压縮応力が生じ る.

$$
\begin{aligned}
& \sigma_{w 1}=\frac{Q_{w 1}}{b \cdot j_{o}} \\
& \sigma_{w 2}=\frac{Q_{w 2}}{b \cdot j_{0}}
\end{aligned}
$$

\section{アーチ作用によるせん断力（図 9)}

上弦材と下弦材において，母材の縁側に配㯰した軸筋の応力 $T_{e x l}$, $T_{\text {ex } 2}$ と開口側に配置した軸筋の応力 $T_{\text {in } 1,} T_{\text {in } 2}$ の許容範围は，トラス 作用の残余分として，それぞれ(10a) 式（10b)式で与えられる.

$$
\begin{aligned}
& -\left(T_{e y}+T_{e y}{ }^{\prime}-C_{w 1}\right) \leq T_{e x 1} \leq\left(T_{e y}+T_{e y}{ }^{\prime}-T_{w 1}\right) \\
& -\left(T_{e y}+T_{e y}{ }^{\prime}-C_{w 2}\right) \leq T_{e x 2} \leq\left(T_{e y}+T_{e y}{ }^{\prime}-T_{w 2}\right) \\
& -\left(T_{i y}-C_{w 1}\right) \leq T_{i n 1} \leq\left(T_{i y}-T_{w 1}\right) \\
& -\left(T_{i y}-C_{w 2}\right) \leq T_{i n 2} \leq\left(T_{i y}-T_{w 2}\right)
\end{aligned}
$$

開口部の上弦材と下弦材における全軸方向銅材の応力 $S_{1}, S_{2}$ は，

$$
\begin{aligned}
& S_{1}=T_{e x 1}+T_{i n 1} \\
& S_{2}=T_{e x 2}+T_{i n 2}
\end{aligned}
$$

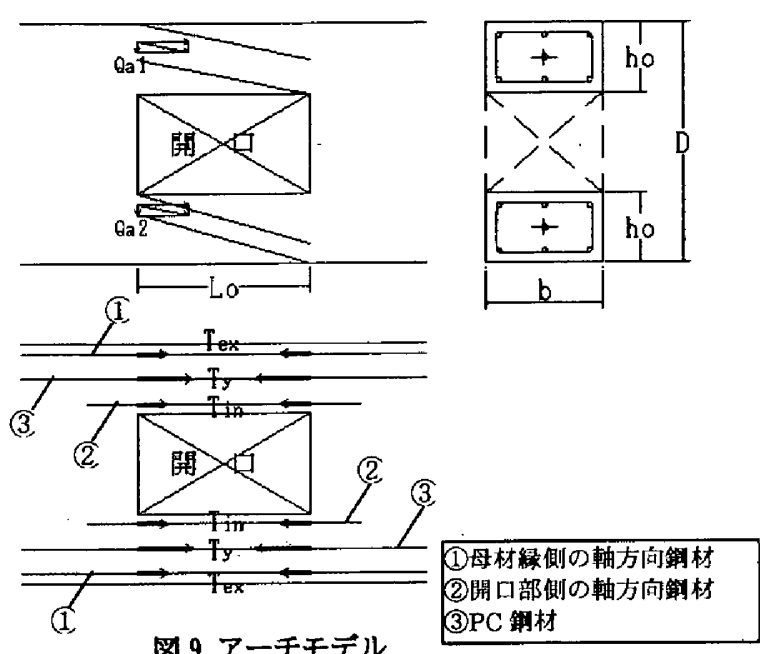


で与えられる.したがって，開口部の上弦材と下弦材における全軸 方向鎆材の底力 $\left(S_{l}, S_{2}\right)$ は (12)式の範囲をとり得る.

$$
\begin{aligned}
& S_{c 1} \leq S_{1} \leq S_{i 1} \\
& S_{c 2} \leq S_{2} \leq S_{t 2} \\
& S_{c 1}=-\left(T_{e y}+T_{e y}{ }^{\prime}+T_{i y}-2 \cdot C_{w 1}\right) \\
& S_{c 2}=-\left(T_{e y}+T_{e y}{ }^{1}+T_{i y}-2 \cdot C_{w 2}\right) \\
& S_{t 1}=T_{e y}+T_{e y}{ }^{1}+T_{i y}-2 \cdot T_{w 1} \\
& S_{t 2}=T_{e y}+T_{e y}{ }^{1}+T_{i y}-2 \cdot T_{w 2}
\end{aligned}
$$

ただし，P1〜P8 の PC 鎆材は上弦材と下弦材の軸心を通っているた め(図6)，(12)式では考虑されていない，したがって，これらの試験 体の $S_{t r}$ と $S_{t 2}$ は PC 鋼材の降伏荷重 $T_{y}$ を付加した(13c)式で与えられ る.

$$
\begin{aligned}
& S_{t 1}=T_{e y}+T_{c y}{ }^{1}+T_{i y}+T_{y}-2 \cdot T_{w 1} \\
& S_{t 2}=T_{e y}+T_{e y}{ }^{1}+T_{i y}+T_{y}-2 \cdot T_{w 2}
\end{aligned}
$$

コンクリート強度もトラス作用の残余分として (14) 式で与えられる.

$$
\begin{aligned}
& \sigma_{a 1}=v \cdot \sigma_{B}-\sigma_{w 1} \\
& \sigma_{a 2}=v \cdot \sigma_{B}-\sigma_{w 2}
\end{aligned}
$$

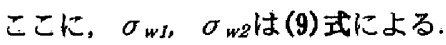

上弦材と下弦材には開口部位直に作用する母材曲げモーメントに よる偶力が軸力として作用している. 上弦材と下弦材のアーチ作用に よるせん断力 $Q_{a l} ， Q_{a 2}$ はこの軸力の大きさに応じ，(10)式～(14) 式 の応力の筙围での極值として(15a)式，(15a)式で与えられる.

$$
Q_{a 1}=C_{o 1}\left[\sqrt{2 \cdot\left(\frac{C_{1}}{C_{o 1}}\right)-\left(\frac{C_{1}}{C_{o 1}}\right)^{2}+\left(\frac{L_{o}}{h_{o}}\right)^{2}}-\left(\frac{L_{o}}{h_{o}}\right)\right]
$$

$$
\begin{aligned}
& \text { ただし， } N_{c 1} \leq N_{1} \leq N_{11} \text { の場合 : } C_{1}=C_{o 1} \\
& N_{1}<N_{t 1} \text { の場合 } \quad: C_{1}=N_{1}+S_{t 1} \\
& N_{1}>N_{c 1} \text { の埸合 } \quad: C_{1}=N+S_{c 1}
\end{aligned}
$$

ここた, $N_{t 1}=C_{o 1}-S_{t 1} \quad N_{c 1}=C_{o 1}-S_{c 1}$

$C_{o 1}=\sigma_{a 1} \cdot b \cdot h_{o} / 2$

$$
Q_{a 2}=C_{o 2}\left[\sqrt{2 \cdot\left(\frac{C_{1}}{C_{o 2}}\right)-\left(\frac{C_{1}}{C_{o 2}}\right)^{2}+\left(\frac{L_{o}}{h_{o}}\right)^{2}}-\left(\frac{L_{o}}{h_{o}}\right)\right]
$$

$$
\begin{aligned}
& \text { ただし， } N_{c 2} \leq N_{2} \leq N_{12} \text { の場合 : } C_{2}=C_{o 2} \\
& N_{2}<N_{t 2} \text { の場合 } \quad: C_{2}=N_{2}+S_{t 2} \\
& N_{2}>N_{c 2} \text { の場合 } \quad: C_{2}=N_{2}+S_{c 2}
\end{aligned}
$$

ここに, $N_{t 2}=C_{o 2}-S_{t 2} \quad N_{c 2}=C_{o 2}-S_{c 2}$ $C_{o 2}=\sigma_{a 2} \cdot b \cdot h_{o} / 2$
開口部の慗局強度 開口部終局強度は上弦材の終局強度 $Q_{u I}$ と下 弦材の終局強度 $Q_{\mu 2}$ の租として(16)式によって与えられる。

$$
Q_{u o}=Q_{u 1}+Q_{u 2}
$$

上弦材の終局強度と下弦材の終局強度は，それぞれトラス作用によ るせん断力とアーチ作用によるせん断力の和として(17)式で与えら れる。

$$
\begin{aligned}
& Q_{u 1}=Q_{w 1}+Q_{a 1} \\
& Q_{u 2}=Q_{w 2}+Q_{a 2}
\end{aligned}
$$

5.2 項の仮定(4)より，母材曲げモーメントによる上弦材と下弦材の 軸方向力 $N_{1}, N_{2}$ (図 10) は(18)式で与えられる.

$$
N_{1}, N_{2}= \pm \frac{Q_{u o} \cdot a_{o}}{d_{o}}
$$

開口部終局強度は，(6)式〜（18）式を满たす解として与えられ. 具 体的には，その解は図 11 に示す収㪉計算によって求まる.

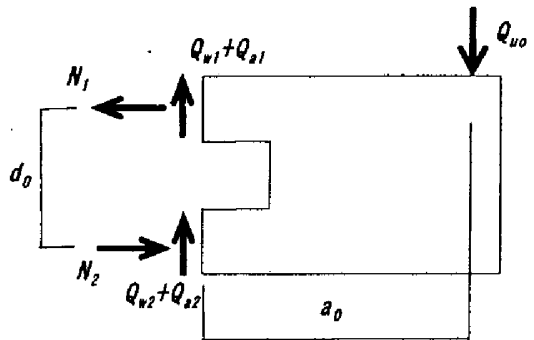

図 10 開口部周りの会い

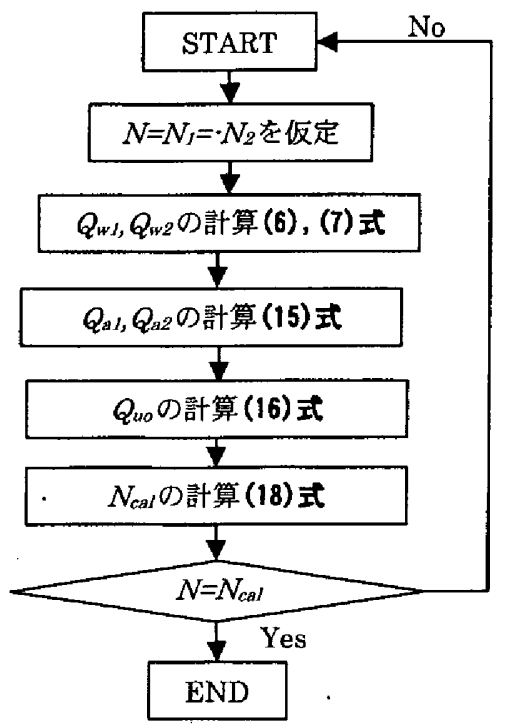

図 11 開口部の終局強度を求めるフロー 


\section{5 実棦結果との比較}

图 12 は, 維軸に終局強度の実験值を母材終局強度で無次元化した ものを，横軸に開口部の終局強度を母材終局強度で無次元化したもの を取り，この贸面に全試験体の結果をプロットしたものである. 表 7 は全試谣体の終局強度と破壤部位の実駼結果と計算による結果の一 覧を示したものである.

計算に際して，コンクリート压縮強度の有効係数レは 0.7 とし, 試 験体の終局強度は母材終局強度と開口部終局強度のうち, 小さい方の 值とした

表 7 と图 12 より，以下のさとが指摘できる.

(1) 図 11 のフローに従った計算精度は比較的高い，(笑験值/計算 値の平均值 $=0.983$, 変動係数 $=7.5 \%$ )

(2) 開口部終局強度 $Q_{u 0} か ゙$ 母材終局強度 $Q_{s u}$ を上回っている(图 12 中, 横軸が 1 を上回る領域に属する)試験体は理論上 母材破壊が開口 部のせん断破壊に先行したと判断されるが, 実際にもこの領域にある 試験体は母材破壊が先行している.

(3) 以上の検討より，母材にトラス作用が形成されないように主筋 の付着を除去した有孔梁試駼体，およびトラス作用とアーチ作用が混 在していると考えられる軸筋に付着のある有孔梁試験体の終局強度 は，曲け卓越型の梁に開口を設けた場合同様，それぞれ独立に算定し た母材之開口部の終局強度のうち,いずれか小さい方の值で評価でき ることが分かる.すなわち，有孔梁母材のせん断終局強度の算定に際 しては，アーチ作用によるせん断力を見込めることになる.

(4) 周知のように、アーチモデルは軸筋が付着を鼠失した曲げせん 断部材に適用されるものである。しかしながら、1 節でも述べたよう に、このような部材のコンクリートの圧絔主ひずみは、縁で最大とな り、緑から離れるにしたがって減少し、対角線方向を結ぶ圧樎束に対 応するようなひずみ渃在しなかったことが示されているゅ.アーチ モデルは付着を缞失した曲げせん断部材の耐力を評価する上では極 めて有効なツールであるといえ、本論でもこれを用いた。しかし、こ のモデルの応力状態については, 実現象と乘離している場合がある。 圧維束が母材に存在しないなら、開口によって母材が本来有している 耐力は低減されることはないと考えられる。(3で述べた結果は、この ようなこ上に起因している。

6 まとめ

せ九断スパン比, 開口の寸法, 位置, 形爿, および主筋の付着の有 無を要因とする 12 体の有孔梁試験体に対して一方向潮増載荷実験を 行い，さらに，上記の試験体に 8 体の PCaPC 有孔梁試験体 5)を加え た 20 体の試験体の終局強度について考察検討を加え, 以下に示す知 見を得た.

(1) 母材のトラス作用が期待できない軸筋の付着を除去した有孔梁 でも十分な耐力を保持し得る場合がある.

(2) 有孔梁のせん断終局強度を計算する方法を示した.この力法は 母材の終局強度と開口部の終局強度をそれぞれ独立に計算し, 有孔梁 としての終局強度は両者のうち,いずれか小さいほうの值とした．母 材のせん断終局強度にはアーチ作用による負担せ九断力も考慮し，開 口部のせん断終局強度は，上弦材と下弦材のトラス作用とア一チ作用 によるせん断力の和で表した.

(3) 上記の方法を用いて付着の有無を主要因とした有孔梁試験体の せん断終局強度を算定し, 実験結果と比較したところ, 計算精度は比

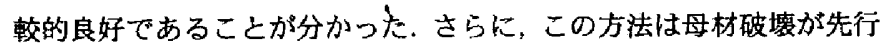
するか開口部破壊が先行するかについても判別できた.

(4) 以上の検討から，母材のア一チ作用によるせん断力は軸筋の付 着の有無に関係なく考慮できることが分かった。

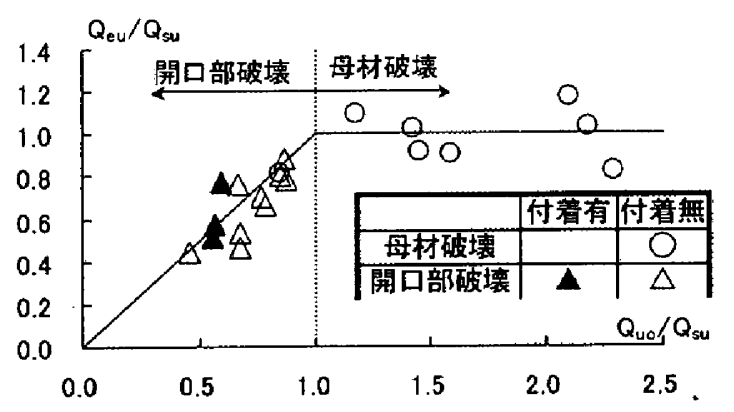

図 $12\left(Q_{e g} / Q_{s}\right)-\left(Q_{n d} / Q_{s p}\right)$ 平面上での破碃モードの判別

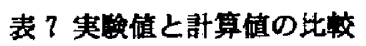

\begin{tabular}{|c|c|c|c|c|c|c|c|c|}
\hline \multirow{2}{*}{$\begin{array}{l}\text { 試 } \\
\text { 䍈 } \\
\text { 体 }\end{array}$} & \multirow{2}{*}{$\begin{array}{c}Q_{e u} \\
(\mathrm{kN})\end{array}$} & \multicolumn{4}{|c|}{ 計算值 $(\mathrm{kN})$} & \multirow{2}{*}{$\frac{Q_{e u}}{Q_{c u}}$} & \multicolumn{2}{|c|}{ 破㐭部位 } \\
\hline & & $Q_{M}$ & $Q_{S}$ & $Q_{v o}$ & $Q_{c u}$ & & 実駼 & 計算* \\
\hline AI & 320.8 & 1213.9 & 2727 & 571.2 & 272.7 & 1.18 & 般材 & 母材 \\
\hline A2 & 204.3 & 809.2 & 2492 & 571.2 & 249.2 & 0.82 & 母材 & 母材 \\
\hline$\overline{A 3}$ & 202.3 & 1235.4 & 285.2 & 2199 & 219.9 & 0.92 & 開口 & 開口 \\
\hline A4 & 212.2 & 823.6 & 259.1 & 219.9 & 219.9 & 0.97 & 母材 & 開口 \\
\hline BI & 235.2 & 471.1 & 302.8 & 179.7 & 179.7 & 1.31 & 開口 & 開口 \\
\hline B2 & 162.1 & 464.9 & 211.3 & 1409 & 140.9 & 1.15 & 開口 & 開口 \\
\hline $\mathrm{Cl}$ & 193.9 & 455.7 & 335.5 & 189.9 & 189.9 & 1.02 & 開口 & 開口 \\
\hline C2 & 115.4 & 454.4 & 258.2 & 1168 & 116.8 & 0.99 & 開口 & 開口 \\
\hline C3 & 162.6 & 452.5 & 316.9 & 177.3 & 177.3 & 0.92 & 開口 & 開口 \\
\hline $\mathrm{C4}$ & 120.4 & 448.1 & 226.5 & 1529 & 152.9 & 0.79 & 開口 & 開口 \\
\hline 01 & 72.8 & 450.6 & 156.7 & 105.8 & 105.8 & 0.69 & 開口 & 開口 \\
\hline D2 & 122.4 & 450.6 & 156.7 & 1373 & 137.3 & 0.89 & 開口 & 開口 \\
\hline$P 1$ & 227.5 & 226.5 & 207.8 & 243.7 & 207.8 & 1.10 & 母材 & 母材 \\
\hline$\overline{P 2}$ & 115.2 & 113.3 & 111.5 & 243.7 & 111.5 & 1.03 & 母材 & 母材 \\
\hline$P 3$ & 287.0 & 399.8 & 323.0 & 2787 & 278.7 & 1.03 & 開口 & 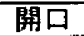 \\
\hline P4 & 159.4 & 199.9 & 175.7 & 278.7 & 175.7 & 0.91 & 母材 & 母材 \\
\hline$\overline{P 5}$ & 252.3 & 397.3 & 313.6 & 265.8 & 265.8 & 0.95 & 開口 & 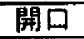 \\
\hline$P 6$ & 173.8 & 198.6 & 1707 & 242.7 & 170.7 & 1.02 & 母材 & 母材 \\
\hline$P 7$ & 225.6 & 404.2 & 338.7 & 267.0 & 267.0 & 0.84 & $\begin{array}{l}\text { 開口 } \\
\end{array}$ & 開口 \\
\hline$P 8$ & 167.7 & 202.1 & 184.0 & 267.0 & 184.0 & 0.91 & 母材 & 母材 \\
\hline
\end{tabular}

Q $Q_{e u}=$ 終局強度の実梌值 $Q_{M}=(3)$ 式による母材の曲げ格局強度

$Q_{S}=(4)$ 式，(5)式による母材のせん断䊏局强度

$Q_{u o}=$ 図 11 のフローに従つた開口部の終局强度

$Q_{c u}=$ 終局强度の計算值 $\left(Q_{M}, Q_{S}, Q_{u v}\right.$ のうち，最小值, 太コシック)

榙算から判断される破壊部位は以下のように決めた

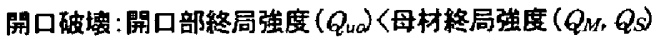

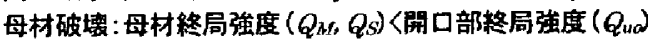

\section{参孝文献}

1）日本建築学会 : 鉄筋コンクリート造建物の終局強度型耐震設計指 針·同解説, pp.104-146, 1990, 10

2）日本建築学会 : 跌筋コンクリート造建物の靭性保障型耐展設計指 針·同解説, pp.138-175，1997，7

3）浜原ほか:プレストレスとコンクリート有孔梁の終局強度型設計 法, 日本建築学会構造系論文報告集, No.442, pp.133-139，1992, 12

4）飯田ほか：軸筋の付着の有無が鉄筋コンクリート部材のせん断 性状に及ぼす影響、日本建築学会構造系論文報告集、No.564， pp.103-108, 2003, 2

5) 浜原ほか：プレキャストプレストレストコンクリート有れ梁の 力学的挙動に関する実験的研究, プレストレストコンクリート第 41 巻 (第 5 号) pp. 14-19，2000

(2005年7月 6 日原稿受理, 2006 年 2 月 16 日探用決定) 